\title{
PENERAPAN ASSET PRICING MODEL (CAPM) TERHADAP KEPUTUSAN INVESTASI PADA INDEKS LQ45 PERIODE 2017- 2019
}

\author{
I Wayan Sunarya \\ Program Studi Teknik Informatika, STMIK STIKOM Indonesia, Denpasar \\ Email: iwayansunarya@gmail.com
}

Masuk : 15-03-2020, revisi: 05-04-2020, diterima untuk diterbitkan :09-04-2020

\begin{abstract}
ABSTRAK
CAPM merupakan sebuah cara dalam memilih saham yang tepat sehingga penelitian ini dilakukan untuk membuat sebuah deksripsi dari saham dari LQ45 dari tahun 2017-2019. Pemilihan sampel dalam penelitian ini yaitu perusahaan Go Public yang digolongkan kedalam Indeks LQ45 yaitu sebuah kelompok perusahaan yang memiliki modal yang cukup besar dan paling liquid selama periode 2017-2019 yang berjumlah 45 perusahaan namun yang digunakan sebagai sampel hanya 33 perusahaan dengan menggunakan cara purposive sampling. Data saham yang diperoleh bersumber dari yahoo finance dan mengambil sumber pustaka untuk sitasi dari berbagai jurnal baik nasional maupun internasional. Penelitian ini dilakukan dengan memilih saham yang efisien yaitu suatu saham yang memiliki nilai $(\mathrm{Ri})>[\mathrm{E}(\mathrm{Ri})]$. Penelitian ini menghasilkan bahwa antara beta maupun expected return terjadi hubungan yang berbanding terbalik, dimana jika nilai beta tinggi maka tingkat pengembalian saham (return) akan rendah, begitu sebaliknya. Dari jumlah 33 perusahaan yang masuk dalam penelitian ini, 24 perusahaan berada pada kondisi efisien dan sisanya 9 perusahaan dalam kondisi yang tidak efisien dari tahun 2017-2019. Adapun beberapa faktor yang menentukan pengelompokkan yaitu dengan membandingkan antara Ri dan $\mathrm{E}(\mathrm{Ri})$, jika $\mathrm{Ri}>\mathrm{E}(\mathrm{Ri}) \mathrm{maka}$ saham tersebut akan dikelompokkan kedalam saham yang efisien namun sebaliknya jika $\mathrm{Ri}<\mathrm{E}(\mathrm{Ri})$ maka saham tersebut akan dikelompokkan kedalam saham yang tidak efisien. Dan apabila hasil dari analisa E(Ri) menunjukkan bahwa saham tersebut efisien maka sebaiknya saham tersebut dibeli dan dijadikan portofolio investasi.
\end{abstract}

Kata Kunci: CAPM, Saham, Return, LQ45

\begin{abstract}
$C A P M$ is a way of choosing the right stock so this research was conducted to make a description of the shares of LQ45 from 2017-2019. The sample selection in this study is the Go Public company classified into the LQ45 Index, which is a group of companies that have a large enough capital and are the most liquid during the 2017-2019 period, amounting to 45 companies but only 33 companies are used as samples by using purposive sampling. The stock data obtained was sourced from Yahoo Finance and took library sources for citations from various national and international journals. This research was conducted by selecting an efficient stock that is a stock that has a value $(R i)>[E(R i)]$. This research results that between beta and expected return there is an inverse relationship, where if the beta value is high then the rate of return of shares will be low, and vice versa. Of the 33 companies included in this study, 24 companies were in an efficient condition and the remaining 9 companies were in an inefficient condition from 2017-2019. As for several factors that determine grouping, by comparing between Ri and $E(R i)$, if $R i>E(R i)$ then the shares will be grouped into efficient shares, but conversely if $R i<E(R i)$ then the shares will be grouped into shares that are not efficient. And if the results of the $E$ (Ri) analysis show that the stock is efficient, then the stock should be bought and used as an investment portfolio.
\end{abstract}

Keywords: CAPM, Stock, Return, LQ45

\section{PENDAHULUAN}

\section{Latar Belakang}

Perekonomian Indonesia yang semakin pesat dipengaruhi oleh pasar domestik Indonesia dalam situasi yang sangat baik dalam menopang perekonomian. Indonesia merupakan negara yang memiliki jumlah penduduk yang terbesar keempat, kekuatan demokrasi terbesar ketiga, dan untuk tingkat Asia Tenggara perekonomian Indonesia berada dalam tingkat ke-13 didunia sehingga hal ini menyebabkan investor lokal dan asing tertarik untuk melakukan investasi di Indonesia dengan harapan mendapatkan keuntungan dalam investasi yang sudah ditanamkan. Sebuah negara dapat dikatakan maju apabila pertumbuhan ekonomi di negara itu sudah 
berkembang secara pesat. Seperti pada tahun 2010 sampai tahun 2015 dimana Indonesia memiliki pertumbuhan ekonomi yang lebih baik dibandingkan dengan pertumbuhan ekonomi periode sebelumnya. Seperti pada tahun 2016 pertumbuhan perekonomian menunjukkan nilai $5,02 \%$ dimana dari angka ini dapat diartikan bahwa Indonesia memiliki nilai ekonomi fundamental dalam kondisi yang sangat baik. Kemudian pada tahun 2016 anka inflasi terkendali pada tingkat 3,02\%, nilai tukar rupiah terjadi apresiasi sebesar 2,6\% dan IHSG mengalami peningkatan nilai menjadi $15,3 \%$. Walaupun Indonesia mengalami pertumbuhan perekonomian yang sangat baik, namun investor tetap memiliki kebijakan didalam melakukan investasi di Indonesia. Investasi yang ditanamkan di Indonesia bisa berbagai macam seperti contohnya dalam bentuk saham. Saham yang dimiliki akan memberikan keuntungan bagi para pemegang saham yang sering dikenal dengan rate of return yang diperoleh sesuai dengan tingkat risiko yang mampu ditanggung oleh para investor (Susanti \& Putra, 2019).

Selain dipengaruhi pasar domestik, perekonomian Indonesia dipengaruhi oleh bursa saham yang dikenal dengan Indeks Harga Saham Gabungan (IHSG). Adapun nilai perubahan persentase IHSG memiliki analisa dalam menghitung nilai return saham-saham di Bursa Efek Indonesia (Adisetiawan, 2017). Dalam melakukan analisa keuntungan dan risiko yang akan dihadapi oleh para investor, maka CAPM dapat dijadikan sebagai sebuah analisa untuk menggambarkan hubungan antara return dan risiko yang terdapat dalam sebuah saham yang diperdagangkan di Bursa Efek Indonesia (Liani, 2017). CPAM merupakan bagian terpenting didalam menentukan model asset pricing didalam keuangan dalam perusahaan. Didalam model CPAM akan menjelaskan tentang risiko antara aset yang dimiliki dengan tingkat investasi yang akan diterima, maka untuk itu analisa ini digunakan untuk menghitung sebuah investasi yang ingin dilakukan dalam sebuah perusahaan (Galea \& Giménez, 2019). Pada saat pasar mengalami keseimbangan maka analisis risiko pada saham akan lebih banyak dipengaruhi oleh indikator Beta $(\beta)$ dengan model capital asset pricising model (CPAM). CPAM terdiri dari Risk market (Rm), Risk free $(R f)$, beta $(\beta)$ dan Expected Return [E(Ri)]. Selain itu analisis CAPM digunakan untuk menentukan peramalan terhadap korelasi risiko dengan return yang diharapkan dan menentukan harga dari aset perusahaan (Ditha Indah et al., 2019). Dengan rasio keuangan yang baik didalam perusahaan akan menciptakan peluang investasi di perusahaan itu sendiri didalam pasar modal walaupun kadang-kadang situasi dalam perusahaan akan mengalami volatilitas dalam hal memberikan nilai investasi kepada para investor (Campbell et al., 2018).

Adapun asumsi yang terdapat didalam CAPM yaitu pasar modal adalah efisien sehingga semua aset yang dimiliki oleh perusahaan yang digolongkan kedalam LQ45 di Bursa Efek Indonesia akan dibagi secara sempurna dan pada saat terjadi jual beli, saham perusahaan tresebut laku terjual. Pada CAPM, portofolio pasar sangat memiliki pengaruh yang cukup besar dimana para investor biasanya akan melakukan diversifikasi dan memilih portofolio optimal berdasarkan pengetahuan terhadap risk dan return yang diberikan oleh saham tersebut. Suatu saham akan memiliki keadaan overvalued dan overvalued, dimana dua keadaan ini memberikan tanda bahwa saham yang dikelompokkan di LQ45 dalam kondisi efisien atau tidak efisien (Riska et al., 2014). Untuk itu CPAM bertujuan untuk menganalisa hubungan secara sistematis dengan tingkat keuntungan yang nanti akan diterima tergantung kepada risiko sistematis yang sering dikenal dengan beta $(\beta)$ yang merupakan bagian tingkat sensitivitas saham terhadap saham itu sendiri (Jegadeesh et al., 2019).

Pada saat saham tersebut mengalami keadaan overvalued, maka saham siap untuk dijual sebaliknya pada saat saham tersebut mengalami undervalued, maka saham tersebut layak untuk dibeli. Hal ini dilakukan oleh para investor dengan menggunakan artian saham yang undervalue 
merupakan saham yang efisien dan menjual saham yang mengalami keadaan overvalue atau tidak efisien. Saham yang ada di Bursa Efek Indonesia ada saham tipe LQ45 dan saham biasa, untuk saham LQ45 berjumlah 45 perusahaan yang memiliki modal dan likuiditas yang tinggi. Dari penelitian dari 45 perusahaan yang digolongkan kedalam saham LQ45, yang dipilih cuma 33 perusahaan yang akan dijadikan sampel dalam penelitian ini. Sampel perusahaan yang berjumlah 33 perusahaan ini dipilih karena saham tersebut selalu masuk dalam kategori LQ45 dari tahun 2017-2019. Adapun data perusahaan kelompok LQ45 yang dimasukkan kedalam penelitian ini yaitu :

Tabel 1. Data Sampel Perusahaan LQ45 dari tahun 2017-2019 Sumber : Yahoo Finance

\begin{tabular}{|c|c|c|}
\hline No. & Kode Emiten & Nama Perusahaan \\
\hline 1 & ADRO & PT. Adaro Energy Tbk \\
\hline 2 & AKRA & PT. AKR Corporindo Tbk \\
\hline 3 & ANTM & PT. Aneka Tambang Tbk \\
\hline 4 & ASII & PT. Astra International Tbk \\
\hline 5 & BBCA & PT. Bank Central Asia Tbk \\
\hline 6 & BBNI & PT. Bank Negara Indonesia Tbk \\
\hline 7 & BBRI & PT. Bank Rakyat Indonesia Tbk \\
\hline 8 & BBTN & PT. Bank Tabungan Negara Tbk \\
\hline 9 & BMRI & PT. Bank Mandiri Tbk \\
\hline 10 & BRPT & PT. Barito Pacific Tbk \\
\hline 11 & BSDE & PT. Bumi Serpong Damai Tbk \\
\hline 12 & EXCL & PT. XL Axiata Tbk. \\
\hline 13 & GGRM & PT. Gudang Garam Tbk. \\
\hline 14 & HMSP & PT. Hanjaya Mandala Sampoerna Tbk \\
\hline 15 & ICBP & PT. Indofood CBP Sukses Makmur Tbk \\
\hline 16 & INCO & PT. Vale Indonesia Tbk \\
\hline 17 & INDF & PT. Indofood Sukses Makmur Tbk \\
\hline 18 & INTP & PT. Indocement Tunggal Prakarsa Tbk \\
\hline 19 & JSMR & PT. Jasa Marga (Persero) Tbk \\
\hline 20 & KLBF & PT. Kalbe Farma Tbk. \\
\hline 21 & LPPF & PT. Matahari Department Store Tbk \\
\hline 22 & $\mathrm{MNCN}$ & PT. Media Nusantara Citra Tbk \\
\hline 23 & PGAS & PT. Perusahaan Gas Negara Tbk \\
\hline 24 & PTBA & PT. Bukit Asam Tbk \\
\hline 25 & PTPP & PT. PP (Persero) Tbk \\
\hline 26 & SCMA & PT. Surya Citra Media Tbk \\
\hline 27 & SMGR & PT. Semen Indonesia (Persero) Tbk \\
\hline 28 & SRIL & PT. Sri Rejeki Isman Tbk \\
\hline 29 & TLKM & PT. Telekomunikasi Indonesia Tbk \\
\hline 30 & UNTR & PT. United Tractors Tbk \\
\hline 31 & UNVR & PT. Unilever Indonesia Tbk \\
\hline
\end{tabular}




\begin{tabular}{lll}
32 & WIKA & PT. Wijaya Karya (Persero) Tbk \\
\hline 33 & WSKT & PT. Waskita Karya (Persero) Tbk \\
\hline
\end{tabular}

Selanjutnya untuk data rata-rata harga saham penutupan dari tahun 2017-2019 sebagai berikut:

Tabel 2. Data Penutupan Harga Saham Perusahaan LQ45 dari tahun 2017-2019 Sumber : Yahoo Finance (Data Diproses)

\begin{tabular}{|c|c|c|c|c|}
\hline \multirow{2}{*}{$\begin{array}{c}\text { No. } \\
1\end{array}$} & \multirow{2}{*}{$\begin{array}{l}\text { Kode Emiten } \\
\text { ADRO }\end{array}$} & \multirow{2}{*}{$\begin{array}{l}\text { Nama Perusahaan } \\
\text { PT. Adaro Energy Tbk }\end{array}$} & \multicolumn{2}{|c|}{$\begin{array}{c}\text { Rata-rata } \\
\text { Penutupan } \\
\text { Harga Saham }\end{array}$} \\
\hline & & & $\mathrm{Rp}$ & 1.634 \\
\hline 2 & AKRA & PT. AKR Corporindo Tbk & $\mathrm{Rp}$ & 1.634 \\
\hline 3 & ANTM & PT. Aneka Tambang Tbk & $\mathrm{Rp}$ & 1.634 \\
\hline 4 & ASII & PT. Astra International Tbk & $\mathrm{Rp}$ & 7.679 \\
\hline 5 & $\mathrm{BBCA}$ & PT. Bank Central Asia Tbk & $\mathrm{Rp}$ & 24.001 \\
\hline 6 & BBNI & PT. Bank Negara Indonesia Tbk & $\mathrm{Rp}$ & 7.927 \\
\hline 7 & BBRI & PT. Bank Rakyat Indonesia Tbk & $\mathrm{Rp}$ & 3.476 \\
\hline 8 & BBTN & PT. Bank Tabungan Negara Tbk & $\mathrm{Rp}$ & 2.625 \\
\hline 9 & BMRI & PT. Bank Mandiri Tbk & $\mathrm{Rp}$ & 7.067 \\
\hline 10 & BRPT & PT. Barito Pacific Tbk & $\mathrm{Rp}$ & 856 \\
\hline 11 & BSDE & PT. Bumi Serpong Damai Tbk & $\mathrm{Rp}$ & 1.551 \\
\hline 12 & EXCL & PT. XL Axiata Tbk. & $\mathrm{Rp}$ & 2.928 \\
\hline 13 & GGRM & PT. Gudang Garam Tbk. & $\mathrm{Rp}$ & 72.294 \\
\hline 14 & HMSP & PT. Hanjaya Mandala Sampoerna Tbk & $\mathrm{Rp}$ & 3.609 \\
\hline 15 & ICBP & PT. Indofood CBP Sukses Makmur Tbk & $\mathrm{Rp}$ & 9.434 \\
\hline 16 & INCO & PT. Vale Indonesia Tbk & $\mathrm{Rp}$ & 3.117 \\
\hline 17 & INDF & PT. Indofood Sukses Makmur Tbk & $\mathrm{Rp}$ & 7.447 \\
\hline 18 & INTP & PT. Indocement Tunggal Prakarsa Tbk & $\mathrm{Rp}$ & 18.834 \\
\hline 19 & JSMR & PT. Jasa Marga (Persero) Tbk & $\mathrm{Rp}$ & 5.189 \\
\hline 20 & KLBF & PT. Kalbe Farma Tbk. & $\mathrm{Rp}$ & 1.532 \\
\hline 21 & LPPF & PT. Matahari Department Store Tbk & $\mathrm{Rp}$ & 8.193 \\
\hline 22 & $\mathrm{MNCN}$ & PT. Media Nusantara Citra Tbk & $\mathrm{Rp}$ & 1.284 \\
\hline 23 & PGAS & PT. Perusahaan Gas Negara Tbk & $\mathrm{Rp}$ & 2.189 \\
\hline 24 & PTBA & PT. Bukit Asam Tbk & $\mathrm{Rp}$ & 3.103 \\
\hline 25 & PTPP & PT. PP (Persero) Tbk & $\mathrm{Rp}$ & 2.384 \\
\hline 26 & SCMA & PT. Surya Citra Media Tbk & $\mathrm{Rp}$ & 2.092 \\
\hline 27 & SMGR & PT. Semen Indonesia (Persero) Tbk & $\mathrm{Rp}$ & 10.655 \\
\hline 28 & SRIL & PT. Sri Rejeki Isman Tbk & $\mathrm{Rp}$ & 335 \\
\hline 29 & TLKM & PT. Telekomunikasi Indonesia Tbk & $\mathrm{Rp}$ & 4.029 \\
\hline 30 & UNTR & PT. United Tractors Tbk & $\mathrm{Rp}$ & 9.332 \\
\hline 31 & UNVR & PT. Unilever Indonesia Tbk & $\mathrm{Rp}$ & 28.885 \\
\hline 32 & WIKA & PT. Wijaya Karya (Persero) Tbk & $\mathrm{Rp}$ & 1.935 \\
\hline 33 & WSKT & PT. Waskita Karya (Persero) Tbk & $\mathrm{Rp}$ & 2.053 \\
\hline
\end{tabular}


Adapun beberapa penelitian yang dilakukan oleh Wildan Deny et al. (2015) tentang penggunaan analisa CAPM dalam menentukan saham efisien atau tidak efisien, dimana hasil yang dihasilkan yaitu dari 37 sampel perushaaan terdapat sebanyak 21 saham yang digolongkan efisien dan 16 saham yang digolongan saham yang tidak efisien. Selain itu hasil penelitian yang dilakukan oleh Riska et al. (2014) menyatakan bahwa terdapat enam perusahaan yang dapat dikelompokkan kedalam saham efisien dan satu saham yang tidak efisien. Disamping itu juga penelitian yang dilakukan oleh Susanti \& Putra (2019) menyatakan terdapat 10 saham LQ45 yang digolongkan kedalam sahan yang efisien sedangkan sisanya 10 saham LQ45 digolongan kedalam saham yang tidak efisien.

\section{Rumusan Masalah}

Dari latar belakang yang sudah dijelaskan maka didapat rumusan masalah sebagai berikut :

1. Bagaimanakah tingkat return dan risk dengan menggunakan metode CPAM dalam menentukan keputusan investasi pada Indeks LQ45 dari tahun 2017-2019 ?

2. Bagaimanakah pengelompokkan dan penilaian Indeks LQ45 berdasarkan tingkat efisiensi dari tahun 2017-2019?

\section{METODE PENELITIAN}

Adapun teknik analisis data menggunakan analisis kuantitatif deskriptif. Adapun populasi terdiri dari Indeks LQ45 dari tahun 2017-2019. Untuk data sekunder dalam penelitian ini diperoleh dari berbagai pihak seperti Library Research dan Online Research juga diterapkan dalam penelitian ini. Sedangkan teknik pengambilan sampel menggunakan metode purposive sampling.

\section{Teknik Analisa Data}

\section{Tingkat Pengembalian Saham Individu atau Return Individual (Ri)}

Menurut Susanti \& Putra (2019) menyatakan tingkat pengembalian saham individu atau sering disingkat dengan Ri (Return Individual) merupakan analisa untuk menghitung tingkat return suatu saham dalam periode tertentu. Adapun cara menghitung tingkat pengembalian saham individu yaitu :

$\mathrm{R}_{\mathrm{i}}=\frac{P_{t}-\left(P_{t-1}\right)}{P_{t-1}}$

Dimana :

$\mathrm{R}_{\mathrm{i}} \quad=$ Tingkat pengembalian saham individu

$\mathrm{P}_{\mathrm{t}} \quad=$ Harga saham periode $\mathrm{t}$

$\mathrm{P}_{\mathrm{t}-1} \quad=$ Harga saham periode $\mathrm{t}-1$

\section{Tingkat Pengembalian Pasar atau Return Market (Rm)}

Untuk data analisa tingkat pengembalian pasar yang digunakan bersumber dari Indeks Harga Saham Gabungan. Indeks Harga Saham Gabungan merupakan salah satu analisa yang terdiri dari data harga saham secara keseluruhan yang memiliki kekuatan yang sangat berpengaruh dalam peristiwa-peristiwa perekonomian yang terjadi di Indonesia (Ni Wayan Sri \& Masithah, 2016). Menurut Susanti \& Putra (2019), rumus yang digunakan untuk menghitung tingkat pengembalian pasar sebagai berikut :

$$
\mathrm{R}_{\mathrm{m}}=\frac{I H S G_{t}-I H S G_{t-1}}{I H S G_{t-1}}
$$


Dimana :

$\mathrm{R}_{\mathrm{m}} \quad=$ Tingkat pengembalian pasar

$\mathrm{IHSG}_{\mathrm{t}}=$ Indeks harga saham periode $\mathrm{t}$

$\mathrm{IHSG}_{\mathrm{t}-1}=$ Indeks harga saham periode $\mathrm{t}-1$

\section{Risk Free (Rf)}

Risk free merupakan analisis untuk menghitung tingkat pengembalian bebas risiko. Adapun data yang digunakan didalam perhitungan Risk free ini yaitu Sertifikasi Bank Indonesia (Susanti \& Putra, 2019).

\section{Analisa Beta Saham $(\beta \mathbf{i})$}

Menurut Siti \& Yaya (2018) salah satu cara dalam menghitung risiko sistematik yaitu dengan menggunakan analisa beta. Analisa beta merupakan sebuah proses analisa pergerakan nilai return dalam sebuah sekuritas atau dapat juga dikatakan sebagai sebuah analisa terhadap nilai tingkat pengembalian pasar. Rumus yang digunakan dalam menghitung nilai Beta Saham yaitu : (Susanti \& Putra, 2019)

$\beta_{i}=\frac{\sigma i m}{\sigma^{2} m}$

Dimana :

$\beta_{\mathrm{i}}=$ Beta saham

$\sigma i m=$ Kovarian return pasar

$\sigma^{2} m=$ Varian pasar

\section{Analisa Tingkat Pengembalian yang diharapkan [E(Ri)]}

Return ekspektasi (expected return) merupakan salah satu analisa yang bertujuan untuk pengambilan kebijakan dalam melakukan investasi. Analisa hasil investasi yang diharapkan memiliki peranan yang sangat penting dibandingkan dengan analisa investasi lainnya (Alifiani, 2017). Menurut Susanti \& Putra (2019), analisa tingkat pengembalian yang diharapkan ini juga dapat membuat sebuah perhitungan antara risiko dan hasil investasi yang diharapkan dengan menggunakan rumus :

$\mathrm{E}(\mathrm{Ri})=\mathrm{Rf}+\beta \mathrm{i}[\mathrm{E}(\mathrm{Rm})-\mathrm{Rf}]$

Dimana :

$\mathrm{E}(\mathrm{Ri})=$ Tingkat pengembalian yang diharapkan

$\mathrm{Rf} \quad=$ Tingkat pengembalian bebas risiko

$\mathrm{Bi}=$ Tingkat risiko sistematis masing-masing saham

$\mathrm{E}(\mathrm{Rm})=$ Tingkat pengembalian yang diharapkan atas portofolio saham.

\section{Grafik Security Market Line (SML)}

Grafik SML adalah sebuah analisa dari model CAPM yang menggambarkan hubungan [E(Ri)] dengan risiko yang sistematis $(\beta)$. Adapun analisa di dalam SML yaity jika semakin besar nilai dari beta suatu saham, maka expected return dari investasi akan semakin besar (Jylh ̈̈, 2018).

\section{HASIL DAN PEMBAHASAN}

\section{Pengembalian Saham Individu}

Keuntungan dalam saham yang sering disebut dengan deviden sebagai bentuk pembagian keuntungan bagi para pemegang saham adalah salah satu bentuk tingkat pengembalian saham individu. Data closing price bulanan pada saham digunakan untuk menganalisa tingkat pengembalian individu dari masing-masing saham perusahaan LQ45. Berdasarkan analisa 
terhadap 33 saham perusahaan yang digolongkan kedalam LQ45 menghasilkan data pengembalian saham individu sebagai berikut :

Tabel 3. Return Saham Individu Perusahaan LQ45 Tahun 2017-2019

Sumber : Yahoo Finance (Data Diproses)

\begin{tabular}{clcclc}
\hline No. & Kode Emiten & $\mathrm{Ri}$ & No. & Kode Emiten & $\mathrm{Ri}$ \\
\hline 1. & ADRO & $0,30 \%$ & 18. & INTP & $1,26 \%$ \\
\hline 2. & AKRA & $0,29 \%$ & 19. & JSMR & $0,86 \%$ \\
\hline 3. & ANTM & $-0,30 \%$ & 20. & KLBF & $0,46 \%$ \\
\hline 4. & ASII & $-0,24 \%$ & 21. & LPPF & $-2,57 \%$ \\
\hline 5. & BBCA & $2,27 \%$ & 22. & MNCN & $0,80 \%$ \\
\hline 6. & BBNI & $1,19 \%$ & 23. & PGAS & $0,00 \%$ \\
\hline 7. & BBRI & $1,92 \%$ & 24. & PTBA & $0,99 \%$ \\
\hline 8. & BBTN & $0,86 \%$ & 25. & PTPP & $-1,26 \%$ \\
\hline 9. & BMRI & $1,06 \%$ & 26. & SCMA & $-1,50 \%$ \\
\hline 10. & BRPT & $23,99 \%$ & 27. & SMGR & $1,31 \%$ \\
\hline 11. & BSDE & $-0,81 \%$ & 28. & SRIL & $0,70 \%$ \\
\hline 12. & EXCL & $0,66 \%$ & 29. & TLKM & $0,21 \%$ \\
\hline 13. & GGRM & $-0,15 \%$ & 30. & UNTR & $0,25 \%$ \\
\hline 14. & HMSP & $-1,44 \%$ & 31. & UNVR & $0,19 \%$ \\
\hline 15. & ICBP & $0,89 \%$ & 32. & WIKA & $0,10 \%$ \\
\hline 16. & INCO & $2,12 \%$ & 33. & WSKT & $-0,82 \%$ \\
\hline 17. & INDF & $0,15 \%$ & & & \\
\hline
\end{tabular}

Pada Tabel 3. Return Saham Individu Perusahaan LQ45 Tahun 2017-2019, dapat dilihat bahwa perusahaan dengan return saham yang paling tertinggi yaitu PT Barito Pacific Tbk (BRPT) yaitu dengan nilai $\mathrm{Ri}$ sebesar 23,99\% dan tingkat return saham yang paling terendah terdapat pada perusahaan Matahari Department Store (LPPF) yaitu sebesar -2,57\%. Hasil penelitian ini berbeda yang dilakukan oleh Susanti \& Putra (2019) dimana hasil penelitian perusahaan LQ45 dari tahun 2012-2016 yang didapat yaitu nilai return saham tertinggi dipegang oleh Indofood Sukses Makmur, Tbk (ICBP) dengan nilai Ri sebesar 3,18\% dan nilai return saham yang paling terendah dipegang oleh Semen Indonesia (Persero) Tbk (SMGR) sebesar -1,1\%.

\section{Pengembalian Pasar}

Untuk analisa perhitungan terhadap pengembalian pasar, sumber data yang digunakan yaitu data Indeks Saham Gabungan (IHSG). Indeks Saham Gabungan ini digunakan karena mampu mewakili keseluruhan aktifitas perdagangan saham yang terdapat didalam Bursa Efek Indonesia (BEI).

Tabel 4. Return Pasar (IHSG) Tahun 2017-2019

Sumber : Yahoo Finance (Data Diproses)

\begin{tabular}{clcccccc}
\hline No. & \multicolumn{1}{c}{ Bulan } & IHSG & Return & No. & Bulan & IHSG & Return \\
\hline 1. & Januari 2017 & $6.299,54$ & $36,50 \%$ & 19. & Juli 2018 & $5.799,24$ & $-2,31 \%$ \\
\hline 2. & Februari 2017 & $6.011,83$ & $-4,57 \%$ & 20. & Agustus 2018 & $5.983,59$ & $3,18 \%$ \\
\hline 3. & Maret 2017 & $6.228,32$ & $3,60 \%$ & 21. & September 2018 & $5.994,60$ & $0,18 \%$ \\
\hline 4. & April 2017 & $6.169,10$ & $-0,95 \%$ & 22. & Oktober 2018 & $6.188,99$ & $3,24 \%$ \\
\hline 5. & Mei 2017 & $6.328,47$ & $2,58 \%$ & 23. & November 2018 & $6.597,22$ & $6,60 \%$ \\
\hline 6. & Juni 2017 & $6.390,50$ & $0,98 \%$ & 24. & Desember 2018 & $6.605,63$ & $0,13 \%$ \\
\hline 7. & Juli 2017 & $6.358,63$ & $-0,50 \%$ & 25. & Januari 2019 & $6.355,65$ & $-3,78 \%$ \\
\hline 8. & Agustus 2017 & $6.209,12$ & $-2,35 \%$ & 26. & Februari 2019 & $5.952,14$ & $-6,35 \%$ \\
\hline 9. & September 2017 & $6.455,35$ & $3,97 \%$ & 27. & Maret 2019 & $6.005,78$ & $0,90 \%$ \\
\hline
\end{tabular}




\begin{tabular}{|c|c|c|c|c|c|c|c|}
\hline 10. & Oktober 2017 & $6.468,75$ & $0,21 \%$ & 28. & April 2019 & $5.900,85$ & $-1,75 \%$ \\
\hline 11. & November 2017 & $6.443,35$ & $-0,39 \%$ & 29. & Mei 2019 & $5.864,06$ & $-0,62 \%$ \\
\hline 12. & Desember 2017 & $6.532,97$ & $1,39 \%$ & 30. & Juni 2019 & $5.840,94$ & $-0,39 \%$ \\
\hline 13. & Januari 2018 & $6.194,50$ & $-5,18 \%$ & 31. & Juli 2019 & $5.829,71$ & $-0,19 \%$ \\
\hline 14. & Februari 2018 & $6.056,12$ & $-2,23 \%$ & 32. & Agustus 2019 & $5.738,15$ & $-1,57 \%$ \\
\hline 15. & Maret 2018 & $5.831,65$ & $-3,71 \%$ & 33. & September 2019 & $5.685,30$ & $-0,92 \%$ \\
\hline 16. & April 2018 & $5.976,55$ & $2,48 \%$ & 34. & Oktober 2019 & $5.568,11$ & $-2,06 \%$ \\
\hline 17. & Mei 2018 & $6.018,46$ & $0,70 \%$ & 35. & November 2019 & $5.386,69$ & $-3,26 \%$ \\
\hline \multirow[t]{5}{*}{18.} & Juni 2018 & $5.936,44$ & $-1,36 \%$ & 36. & Desember 2019 & $5.294,10$ & $-1,72 \%$ \\
\hline & & & & & & Jumlah & $20,47 \%$ \\
\hline & & & & & & $\mathrm{E}(\mathrm{Rm})$ & $-5,79 \%$ \\
\hline & & & & & & Maksimum & $36,50 \%$ \\
\hline & & & & & & Minimum & $-6,35 \%$ \\
\hline
\end{tabular}

Pada tabel 4 menjelaskan tentang Return Pasar Perusahaan LQ45 dari tahun 2017-2019 dimana dapat dianalisa bahwa nilai rata-rata pengembalian pasar $(\mathrm{Rm})$ yaitu $-5,79 \%$. Dari analisa juga dapat dijelaskan bahwa pada bulan Februari 2019 memiliki tingkat pengembalian pasar terendah yaitu $-6,35 \%$ sehingga dapat dijelaskan bahwa pada bulan tersebut perdagangan IHSG mengalami sebuah keadaan yang tidak menguntungkan bagi para investor. Beda dengan bulan Januari 2017 dari data tabel diatas pengembalian pasar tertinggi yaitu 36,50\%, hal ini terjadi karena ada lompatan sangat jauh dari IHSG dimana pada bulan Desember 2016, nilai IHSG sebesar 4.615,16 sedangkan pada bulan Januari 2017 nilai IHSG sebesar 6.299,54 sehingga bulan Januari 2017 tingkat return IHSG sebesar 36,50\%, hal ini dapat diartikan indeks IHSG mengalami sebuah keadaan yang menguntungkan bagi para investor. Hasil yang didapatkan dalam tabel 4 berbeda dengan hasil penelitian yang dilakukan oleh Susanti \& Putra (2019) dimana hasil penelitian terhadap perusahaan LQ45 dari tahun 2012-2016 mendapatkan hasil return market sebesar $1 \%$.

\section{Pengembalian Bebas Risiko}

Untuk sumber data dari pengembalian bebas risiko bersumber dari tingkat suku bunga Bank Indonesia. Adapun data hasil tingkat risk free (Rf) adalah sebagai berikut :

Tabel 5. Hasil tingkat Risk Free (Rf) dari tahun 2017-2019

Sumber : http://www.bi.go.id (Data Diproses)

\begin{tabular}{clrrc}
\hline No. & \multicolumn{1}{c}{ Bulan } & Tahun 2017 & Tahun 2018 & Tahun 2019 \\
\hline 1. & Januari & $4,75 \%$ & $4,25 \%$ & $6,00 \%$ \\
\hline 2. & Februari & $4,75 \%$ & $4,25 \%$ & $6,00 \%$ \\
\hline 3. & Maret & $4,75 \%$ & $4,25 \%$ & $6,00 \%$ \\
\hline 4. & April & $4,75 \%$ & $4,25 \%$ & $6,00 \%$ \\
\hline 5. & Mei & $4,75 \%$ & $4,50 \%$ & $6,00 \%$ \\
\hline 6. & Juni & $4,75 \%$ & $5,25 \%$ & $6,00 \%$ \\
\hline 7. & Juli & $4,75 \%$ & $5,25 \%$ & $5,75 \%$ \\
\hline 8. & Agustus & $4,50 \%$ & $5,50 \%$ & $5,50 \%$ \\
\hline 9. & September & $4,25 \%$ & $5,75 \%$ & $5,25 \%$ \\
\hline 10. & Oktober & $4,25 \%$ & $5,75 \%$ & $5,00 \%$ \\
\hline
\end{tabular}




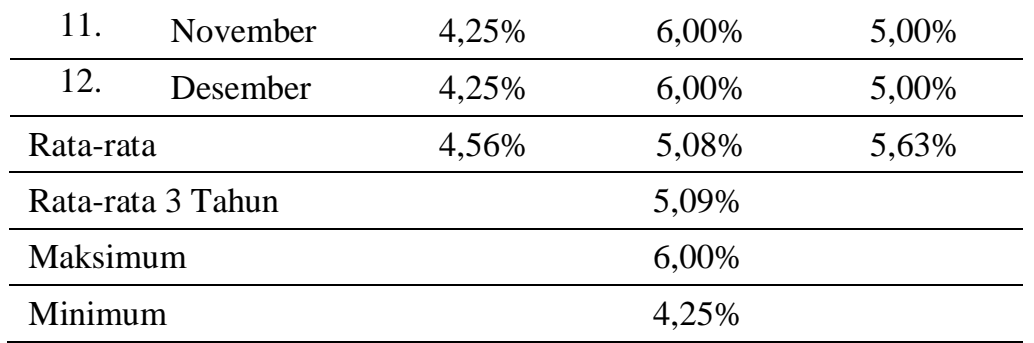

Pada tabel 5 diatas, hasil perhitungan $R f$ dari tahun 2017-2019 dapat diketahui bahwa rata-rata nilai risk free dari tahun 2017-2019 adalah 5,09\% dengan tingkat risk free rate tertinggi sebesar $6,00 \%$ dan terendah sebesar $4,25 \%$. Hasil ini berbeda dengan penelitian yang dilakukan oleh Susanti \& Putra (2019) dimana untuk tahun 2012-2016 untuk nilai risk free yaitu sebesar 6,66\%.

\section{Risiko Sistematis Saham Individu}

Risiko sistematis merupakan sebuah risiko yang dimiliki oleh saham yang sering disebut dengan nilai Beta $(\beta \mathrm{i})$. Hubungan antara tingkat pengembalian suatu saham terhadap tingkat pengembalian pasar akan terlihat dengan cara menghitung beta saham. Adapun data tentang analisa risiko sistematis (Beta) dari 33 saham perusahaan dalam penelitian ini bersumber dari data yahoo finance yaitu :

Tabel 6. Hasil perhitungan Risiko Sistematis Saham Individu ( $\beta i)$

Sumber : Yahoo Finance

\begin{tabular}{|c|c|c|c|}
\hline No. & Kode Emiten & Nama Perusahaan & Beta \\
\hline 1 & ADRO & PT. Adaro Energy Tbk & 1,26 \\
\hline 2 & AKRA & PT. AKR Corporindo Tbk & 0,43 \\
\hline 3 & ANTM & PT. Aneka Tambang Tbk & 1,16 \\
\hline 4 & ASII & PT. Astra International Tbk & 0,44 \\
\hline 5 & $\mathrm{BBCA}$ & PT. Bank Central Asia Tbk & 0,34 \\
\hline 6 & BBNI & PT. Bank Negara Indonesia Tbk & 0,70 \\
\hline 7 & BBRI & PT. Bank Rakyat Indonesia Tbk & 0,57 \\
\hline 8 & BBTN & PT. Bank Tabungan Negara Tbk & 0,82 \\
\hline 9 & BMRI & PT. Bank Mandiri Tbk & 0,49 \\
\hline 10 & BRPT & PT. Barito Pacific Tbk & 1,16 \\
\hline 11 & BSDE & PT. Bumi Serpong Damai Tbk & 0,80 \\
\hline 12 & EXCL & PT. XL Axiata Tbk. & 0,28 \\
\hline 13 & GGRM & PT. Gudang Garam Tbk. & 0,20 \\
\hline 14 & HMSP & PT. Hanjaya Mandala Sampoerna Tbk & 0,20 \\
\hline 15 & ICBP & PT. Indofood CBP Sukses Makmur Tbk & $-0,08$ \\
\hline 16 & INCO & PT. Vale Indonesia Tbk & 1,49 \\
\hline 17 & INDF & PT. Indofood Sukses Makmur Tbk & 0,30 \\
\hline 18 & INTP & PT. Indocement Tunggal Prakarsa Tbk & 0,56 \\
\hline 19 & JSMR & PT. Jasa Marga (Persero) Tbk & 0,39 \\
\hline 20 & KLBF & PT. Kalbe Farma Tbk. & 0,62 \\
\hline 21 & LPPF & PT. Matahari Department Store Tbk & 0,72 \\
\hline 22 & $\mathrm{MNCN}$ & PT. Media Nusantara Citra Tbk & 1,10 \\
\hline
\end{tabular}




\begin{tabular}{llll}
23 & PGAS & PT. Perusahaan Gas Negara Tbk & 1,28 \\
\hline 24 & PTBA & PT. Bukit Asam Tbk & 1,39 \\
\hline 25 & PTPP & PT. PP (Persero) Tbk & 1,31 \\
\hline 26 & SCMA & PT. Surya Citra Media Tbk & 0,75 \\
\hline 27 & SMGR & PT. Semen Indonesia (Persero) Tbk & 0,79 \\
\hline 28 & SRIL & PT. Sri Rejeki Isman Tbk & 0,56 \\
\hline 29 & TLKM & PT. Telekomunikasi Indonesia Tbk & $-0,13$ \\
\hline 30 & UNTR & PT. United Tractors Tbk & 0,63 \\
\hline 31 & UNVR & PT. Unilever Indonesia Tbk & 0,19 \\
\hline 32 & WIKA & PT. Wijaya Karya (Persero) Tbk & 0,98 \\
\hline 33 & WSKT & PT. Waskita Karya (Persero) Tbk & 1,04 \\
\hline
\end{tabular}

Dari data pada tabel 6, dapat diketahui hasil perhitungan risiko sistematis saham individu dimana menunjukkan nilai rata-rata dari $\beta$ i sebesar 0,69 yang artinya secara keseluruhan saham perusahaan yang dikelompokkan kedalam LQ45 memiliki risiko sistematis yang kecil dan tidak terlalu sensitif dalam merespon perubahan harga pasar. Hal ini berbeda dengan penelitian yang dilakukan oleh Susanti \& Putra (2019) dimana hasil nilai beta saham yang didapat sebesar 0,1410577 .

\section{Tingkat Pengembalian Diharapkan}

Tingkat keuntungan yang akan diharapkan oleh investor dari investasi saham yang dilakukan sering dikenal denga nama tingkat pengembalian yang diharapkan [E(Ri)]. Hasil perhitungan $\mathrm{E}(\mathrm{Ri})$ adalah sebagai berikut :

Tabel 7. Hasil Perhitungan [E(Ri)] Sumber : Tabel 3 s/d Tabel 6 (Data Diproses)

\begin{tabular}{clllll}
\hline No. & $\begin{array}{c}\text { Kode } \\
\text { Emiten }\end{array}$ & $\begin{array}{c}\text { E(Ri) } \\
\text { CAPM }\end{array}$ & No. & $\begin{array}{c}\text { Kode } \\
\text { Emiten }\end{array}$ & $\begin{array}{c}\text { E(Ri) } \\
\text { CAPM }\end{array}$ \\
\hline 1 & ADRO & $-8,62 \%$ & 18 & INTP & $-1,00 \%$ \\
\hline 2 & AKRA & $0,41 \%$ & 19 & JSMR & $0,85 \%$ \\
\hline 3 & ANTM & $-7,53 \%$ & 20 & KLBF & $-1,65 \%$ \\
\hline 4 & ASII & $0,30 \%$ & 21 & LPPF & $-2,74 \%$ \\
\hline 5 & BBCA & $1,39 \%$ & 22 & MNCN & $-6,88 \%$ \\
\hline 6 & BBNI & $-2,52 \%$ & 23 & PGAS & $-8,83 \%$ \\
\hline 7 & BBRI & $-1,11 \%$ & 24 & PTBA & $-10,03 \%$ \\
\hline 8 & BBTN & $-3,83 \%$ & 25 & PTPP & $-9,16 \%$ \\
\hline 9 & BMRI & $-0,24 \%$ & 26 & SCMA & $-3,07 \%$ \\
\hline 10 & BRPT & $-7,53 \%$ & 27 & SMGR & $-3,50 \%$ \\
\hline 11 & BSDE & $-3,61 \%$ & 28 & SRIL & $-1,00 \%$ \\
\hline 12 & EXCL & $2,04 \%$ & 29 & TLKM & $6,50 \%$ \\
\hline 13 & GGRM & $2,91 \%$ & 30 & UNTR & $-1,76 \%$ \\
\hline 14 & HMSP & $2,91 \%$ & 31 & UNVR & $3,02 \%$ \\
\hline 15 & ICBP & $5,96 \%$ & 32 & WIKA & $-5,57 \%$ \\
\hline 16 & INCO & $-11,12 \%$ & 33 & WSKT & $-6,22 \%$ \\
\hline & & & & &
\end{tabular}


Dari data yang ada dalam tabel 7 , yang dijelaskan bahwa investor yang mengharapkan hasil dari expected return $[\mathrm{E}(\mathrm{Ri})]$ yang tertinggi adalah sebesar 6,50\% yaitu TLKM dan perusahaan dengan expected return terendah [E(Ri)] adalah INCO sebesar $-11,12 \%$. Hasil penelitian ini berbeda yang dilakukan oleh Susanti \& Putra (2019) terhadap nilai [E(Ri)] perusahaan LQ45 dari tahun 2012-2016 dimana hasil yang didapat yaitu nilai [E(Ri)] tertinggi yaitu perusahaan Alam Sutera Realty Tbk dengan nilai sebesar $1,16 \%$ dan untuk perusahaan dengan nilai [E(Ri)] terendah yaitu Indofood CBP Sukses Makmur Tbk sebesar 0,02\%.

\section{Grafik Security Market Line (SML)}

Untuk memberikan ilsutrasi dengan model CAPM maka dibuatlah grafik Security Market Line atau sering dikenal dengan SML. Hubungan antara risiko sistematis atau beta $(\beta)$ dengan expeceted return digambarkan dengan grafik yaitu sebagai berikut:

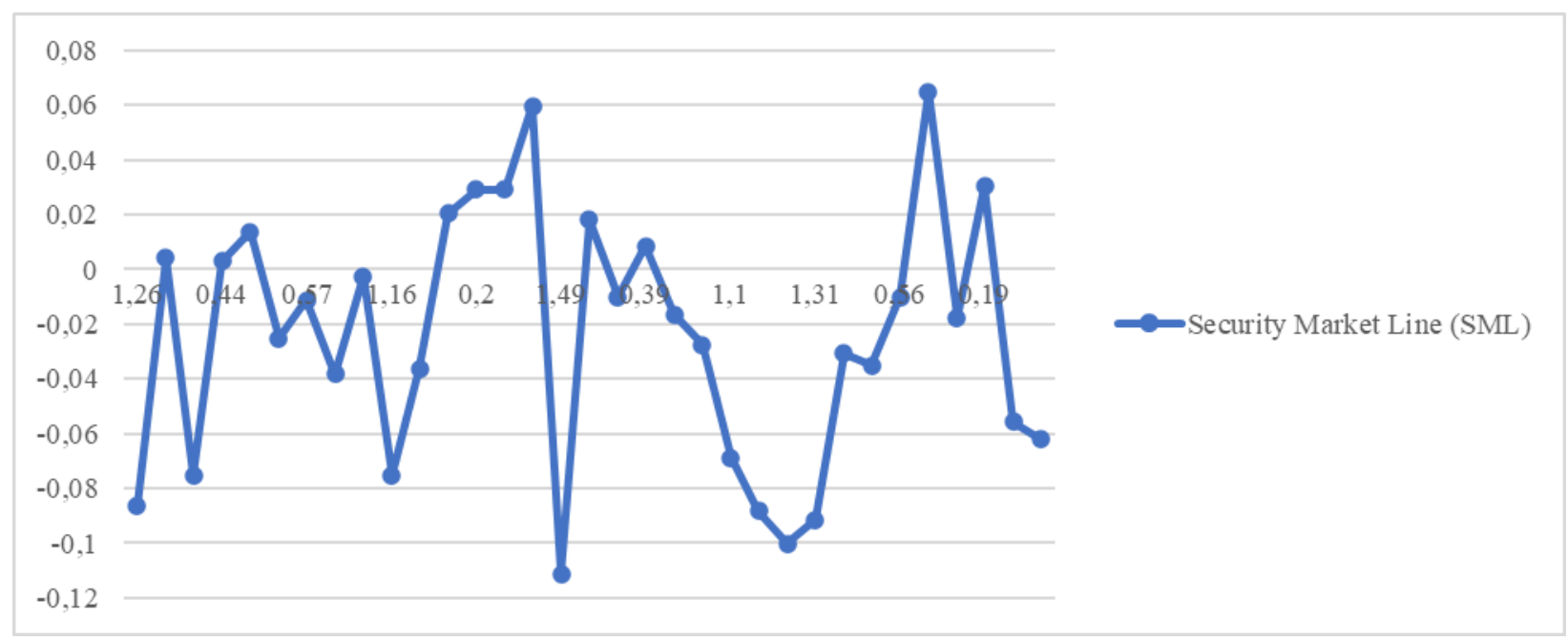

Gambar 1. Grafik Security Market Line (SML)

Sumber Gambar : Tabel 7 (Data Diproses)

\section{Pengklasifikasian Saham}

Menurut Susanti \& Putra (2019), klasifikasi saham dibedakan menjadi dua yaitu saham efisien dan saham tidak efisien. Saham efisien terjadi apabila Ri $>E(R i)$ sebaliknya saham tidak efisien terjadi apabila $\mathrm{Ri}<\mathrm{E}(\mathrm{Ri})$. Untuk saham efisien dapat dijadikan acuan dalam membeli saham dalam Indeks LQ45. Dari analisa yang sudah dijelaskan diatas, maka saham yang digolongkan kedalam saham efisien dan saham tidak efisisen sebagai berikut :

Tabel 8. Pengklasifikasian Saham Indeks LQ45

Sumber: Tabel 3 \& Tabel 7 (Data Diproses)

\begin{tabular}{llccl}
\hline No. & Kode Emiten & Ri & $\begin{array}{c}\text { E(Ri) } \\
\text { CAPM }\end{array}$ & Kategori \\
\hline 1 & ADRO & $0,30 \%$ & $-8,62 \%$ & Efisien \\
\hline 2 & AKRA & $0,29 \%$ & $0,41 \%$ & Tidak Efisien \\
\hline 3 & ANTM & $-0,30 \%$ & $-7,53 \%$ & Efisien \\
\hline 4 & ASII & $-0,24 \%$ & $0,30 \%$ & Tidak Efisien \\
\hline 5 & BBCA & $2,27 \%$ & $1,39 \%$ & Efisien \\
\hline
\end{tabular}




\begin{tabular}{|c|c|c|c|c|}
\hline 6 & BBNI & $1,19 \%$ & $-2,52 \%$ & Efisien \\
\hline 7 & BBRI & $1,92 \%$ & $-1,11 \%$ & Efisien \\
\hline 8 & BBTN & $0,86 \%$ & $-3,83 \%$ & Efisien \\
\hline 9 & BMRI & $1,06 \%$ & $-0,24 \%$ & Efisien \\
\hline 10 & BRPT & $23,99 \%$ & $-7,53 \%$ & Efisien \\
\hline 11 & BSDE & $-0,81 \%$ & $-3,61 \%$ & Efisien \\
\hline 12 & EXCL & $0,66 \%$ & $2,04 \%$ & Tidak Efisien \\
\hline 13 & GGRM & $-0,15 \%$ & $2,91 \%$ & Tidak Efisien \\
\hline 14 & HMSP & $-1,44 \%$ & $2,91 \%$ & Tidak Efisien \\
\hline 15 & ICBP & $0,89 \%$ & $5,96 \%$ & Tidak Efisien \\
\hline 16 & INCO & $2,12 \%$ & $-11,12 \%$ & Efisien \\
\hline 17 & INDF & $0,15 \%$ & $1,83 \%$ & Tidak Efisien \\
\hline 18 & INTP & $1,26 \%$ & $-1,00 \%$ & Efisien \\
\hline 19 & JSMR & $0,86 \%$ & $0,85 \%$ & Efisien \\
\hline 20 & KLBF & $0,46 \%$ & $-1,65 \%$ & Efisien \\
\hline 21 & LPPF & $-2,57 \%$ & $-2,74 \%$ & Efisien \\
\hline 22 & $\mathrm{MNCN}$ & $0,80 \%$ & $-6,88 \%$ & Efisien \\
\hline 23 & PGAS & $0,00 \%$ & $-8,83 \%$ & Efisien \\
\hline 24 & PTBA & $0,99 \%$ & $-10,03 \%$ & Efisien \\
\hline 25 & PTPP & $-1,26 \%$ & $-9,16 \%$ & Efisien \\
\hline 26 & SCMA & $-1,50 \%$ & $-3,07 \%$ & Efisien \\
\hline 27 & SMGR & $1,31 \%$ & $-3,50 \%$ & Efisien \\
\hline 28 & SRIL & $0,70 \%$ & $-1,00 \%$ & Efisien \\
\hline 29 & TLKM & $0,21 \%$ & $6,50 \%$ & Tidak Efisien \\
\hline 30 & UNTR & $0,25 \%$ & $-1,76 \%$ & Efisien \\
\hline 31 & UNVR & $0,19 \%$ & $3,02 \%$ & Tidak Efisien \\
\hline 32 & WIKA & $0,10 \%$ & $-5,57 \%$ & Efisien \\
\hline 33 & WSKT & $-0,82 \%$ & $-6,22 \%$ & Efisien \\
\hline
\end{tabular}

Dari data pada tabel 8, dapat dijelaskan bahwa hasil pengklasifikasian saham LQ45 dimana diketahui terdapat 24 perusahaan LQ45 yang sahamnya tergolong kedalam keadaan yang efisien dan sisanya 9 perusahaan yang sahamnya dapat dikelompokkan kedalam saham yang tidak efisien. Adapun beberapa faktor yang menentukan pengelompokkan yaitu dengan membandingkan antara $\mathrm{Ri}$ dan $\mathrm{E}(\mathrm{Ri})$, jika $\mathrm{Ri}>\mathrm{E}(\mathrm{Ri})$ maka saham tersebut akan dikelompokkan kedalam saham yang efisien namun sebaliknya jika $\mathrm{Ri}<\mathrm{E}(\mathrm{Ri})$ maka saham tersebut akan dikelompokkan kedalam saham yang tidak efisien. Dan apabila hasil dari analisa E(Ri) menunjukkan bahwa saham tersebut efisien maka sebaiknya saham tersebut dibeli dan dijadikan portofolio investasi. Hal ini berbeda penelitian yang dilakukan oleh Susanti \& Putra (2019) dimana dari hasil analisa terhadap sampel 20 perusahaan LQ45 dari tahun 2012-2016 yang digolongkan kedalam saham efisien sebanyak 10 perusahaan dan sisanya sebanyak 10 perusahaan dikelompokkan kedalam saham yang tidak efisien. 


\section{KESIMPULAN DAN SARAN \\ Kesimpulan}

Dari hasil analisa yang sudah dilakukan memberikan kesimpulan yaitu antara beta dengan expected return terjadi hubungan yang saling terkait yaitu nilai beta yang mempunyai nilai yang tinggi akan memberikan hasil return rendah, begitu juga sebaliknya. Hal ini terlihat dari data pada tabel 8 , ada perbedaan saham yang layak untuk dibeli dan tidak layak untuk dibeli. Saham yang menjadi acuan untuk dibeli adalah saham yang tergolong kedalam saham efisien karena memiliki nilai return individual (Ri) lebih besar dari nilai return individual yang diharapkan $\mathrm{E}(\mathrm{Ri})$. Dari tabel 8, saham yang layak dijadikan koleksi dalam portofolio yaitu saham perusahaan yang memiliki kode ADRO, ANTM, BBCA, BBNI, BBRI, BBTN, BMRI, BRPT, BSDE, INCO, INTP, JSMR, KLBF, LPPF, MNCN, PGAS, PTBA, PTPP, SCMA, SMGR, SRIL, UNTR, WIKA dan WSKT. Sedangkan saham yang tidak layak (tidak efisien) untuk dijadikan koleksi dalam portofolio diantaranya AKRA, ASII, EXCL, GGRM, HMSP, ICBP, INDF, TLKM, UNVR.

\section{Saran}

Adapun saran yang diharapkan yaitu dari hasil penelitian ini memberikan tambahan wawasan dan referensi dari berbagai pihak terutama investor dalam melakukan investasi. Harapan dari penelitian ini dpaat dikembangkan lagi dengan menggunakan metode yang lain seperti melakukan kombinasi CAPM dan Fama \& French.

\section{REFERENSI}

Adisetiawan, R. (2017). Globalisasi Pasar Modal Dunia Dan Pengaruhnya Terhadap Pasar Modal Indonesia. Ekonomis: Journal of Economics and Business, 1(1), 10. https://doi.org/10.33087/ekonomis.v1i1.19

Alifiani, M. A. (2017). Analisis Return dan Risk atas Investasi Saham pada Perusahaan Otomotif dan Komponen Go Publik di Bursa Efek Indonesia Periode 2014-2016. Jurnal Studi Manajemen Bisnis, 1(1). https://jurnal.umk.ac.id/index.php/jsmb/article/view/3760

Campbell, J. Y., Giglio, S., Polk, C., \& Turley, R. (2018). An intertemporal CAPM with stochastic volatility. Journal of Financial Economics, 128(2), 207-233. https://doi.org/10.1016/j.jfineco.2018.02.011

Ditha Indah, F., R. Deni Muhammad, D., \& Nor, N. (2019). Analisis Capital Asset Pricing Model ( Capm ) Dalam Pengambilan Keputusan. Jurnal Ekonomi Dan Bisnis, 20(2), 1118. https://doi.org/http://dx.doi.org/10.30659/ekobis.20.2.11-18

Galea, M., \& Giménez, P. (2019). Local influence diagnostics for the test of mean-variance efficiency and systematic risks in the capital asset pricing model. Statistical Papers, 60(1), 293-312. https://doi.org/10.1007/s00362-016-0838-8

Jegadeesh, N., Noh, J., Pukthuanthong, K., Roll, R., \& Wang, J. (2019). Empirical tests of asset pricing models with individual assets: Resolving the errors-in-variables bias in risk premium estimation. Journal of Financial Economics, 133(2), 273-298. https://doi.org/10.1016/j.jfineco.2019.02.010

JylhÄ, P. (2018). Margin Requirements and the Security Market Line. Journal of Finance, 73(3), 1281-1321. https://doi.org/10.1111/jofi.12616

Liani, M. (2017). Analysis of the Comparison Among Efficient Stocks That Form Portfolio Using Capital Asset Pricing Model (CAPM) and Fama-French Three Factor Model (Case Study on Kompas 100 Companies From 2013-2015). Jurnal Akuntansi, Kewirausahaan Dan Bisnis, 2(1), 76-89. http://www.ejournal.pelitaindonesia.ac.id/ojs32/index.php/KURS/article/view/229

Ni Wayan Sri, A., \& Masithah, A. (2016). Analisis Pengaruh Inflasi, Suku Bunga, Nilai Tukar 
(Kurs) dan Pertumbuhan Produk Domestik Bruto (PDB) Terhadap Indeks Harga Saham Gabungan (IHSG) Studi Kasus pada Perusahaan Properti yang terdaftar di Bursa Efek Indonesia. Jurnal Manajemen Dan Akuntansi, 17(1), 43-52. http://journal.stieikayutangi-bjm.ac.id/index.php/jma/article/view/269

Riska, Y., Topowijono, \& Devi Farah, A. (2014). Penerapan Metode Capm (Capital Asset Pricing Model) Untuk Menentukan Pilihan Investasi Pada Saham (Studi Pada Perusahaan Sektor Consumer Good Industry di Bursa Efek Indonesia Periode 2010-2012). Jurnal Administrasi Bisnis, 13(2), 122-130. http://administrasibisnis.studentjournal.ub.ac.id/

Siti, M., \& Yaya, S. (2018). Faktor-faktor Fundamental yang berpengaruh terhadap Beta Saham (Studi Kasus Perusahaan Finance yang terdaftar di Bursa Efek Indonesia Periode 20132016). The Journal of Business and Management Research, 1(2), 127-132. http://jurnal.uniyap.ac.id/index.php/pasca/article/view/459

Susanti, N., \& Putra, O. E. (2019). Penerapan Asset Pricing Model (Capm) Terhadap Keputusan Investasi Pada Indeks Lq 45 Periode 2012-2016. Jurnal Muara Ilmu Ekonomi Dan Bisnis, 2(2), 366. https://doi.org/10.24912/jmieb.v2i2.1556

Wildan Deny, S., Suhadak, \& Devi Farah, A. (2015). Penggunaan Metode Capital Asset Pricing Model (CAPM) dalam menentukan Saham Efisien (Studi pada Saham-Saham Perusahaan yang terdaftar di Indeks Kompas100 Periode 2010-2013). Jurnal Administrasi Bisnis, 25(1),

http://administrasibisnis.studentjournal.ub.ac.id/index.php/jab/article/view/971 